\title{
THE CONTROL OF BRACKEN WITH ASULAM
}

\author{
A. G. WASMUTH \\ May and Baker (New Zealand) Ltd., Lower Hutt
}

\section{Summary}

The results of a series of replicated and unreplicated trials have shown after one year's observation, that asulam at 4.5 to 9.0 $\mathrm{kg} / \mathrm{ha}$ gives control of bracken (Pteridium aquilinum var. esculentum) in New Zealand. Timing of application is of importance and asulam can be applied effectively during a 4 to 6 week period when the majority of fronds to be sprayed are fully unfurled, but still soft. Applications of the same rates made to partially unfurled bracken fronds in newly planted forestry areas, gave 12 months bracken suppression which was sufficient to avoid the need to release Pinus radiata by hand. Observations indicated that these "releasing" applications gave no significant control of regrowth 12 months after spraying.

\section{INTRODUCTION}

THE use of asulam for the control of bracken (Pteridium aquilinum) in the United Kingdom, was first described by Holroyd et al in 1970. They established that satisfactory control of bracken could be obtained for at least 2 years following applications of asulam of 4.5 and $9.0 \mathrm{~kg} / \mathrm{ha}$. More recent work by Soper (1972); Scragg et al (1972); and Martin et al (1972), confirms and expands on these results.

In 1971 the author established a range of trials with asulam aimed at establishing:

(a) Whether asulam would give long term control of the New Zealand variety of bracken (Pteridium aquilinum var. esculentum).

(b) Whether asulam would give any suppression of this bracken in the same season of application.

The first part of this investigation was aimed at studying the use of asulam for long term bracken control in agricultural, amenity and waste areas, and in forest land preparation. The second part of the series of trials was designed specifically to determine the use of asulam for releasing newly planted Pinus radiata.

This paper describes the results of these investigations after 2 years.

\section{LONG TERM BRACKEN CONTROL}

Experimental

At 1 site only, applications of asulam were made to randomised plots of 0.036 ha replicated 3 times. The rates employed were $2.2,4.5$ and $9.0 \mathrm{~kg} / \mathrm{ha}$ in 95 litres of water/ha. Each was applied at a different stage of frond development as below. 


\section{Scrub Weeds}

Time 1. Crook stage (hook or crozier stage no pinnae expanded).

Time 2 Fronds partially unfurled (all fronds approximately half unfurled).

Time 3 Fronds fully expanded but approximately $25 \%$ of blade still soft.

Time 4. Fronds all expanded with hardened cuticles.

No standard or comparative treatment was applied. All plots were mechanically defoliated in mid winter before and after the applications, to help synchronise frond emergence and remove complications for assessments caused by over-wintered fronds.

Results were assessed on replicated square metre quadrats, 8 to 12 months after treatment by counting all frond regrowth at the crook stage. Results

The results of the assessments carried out 8 to 12 months after application are seen in Figure 1.

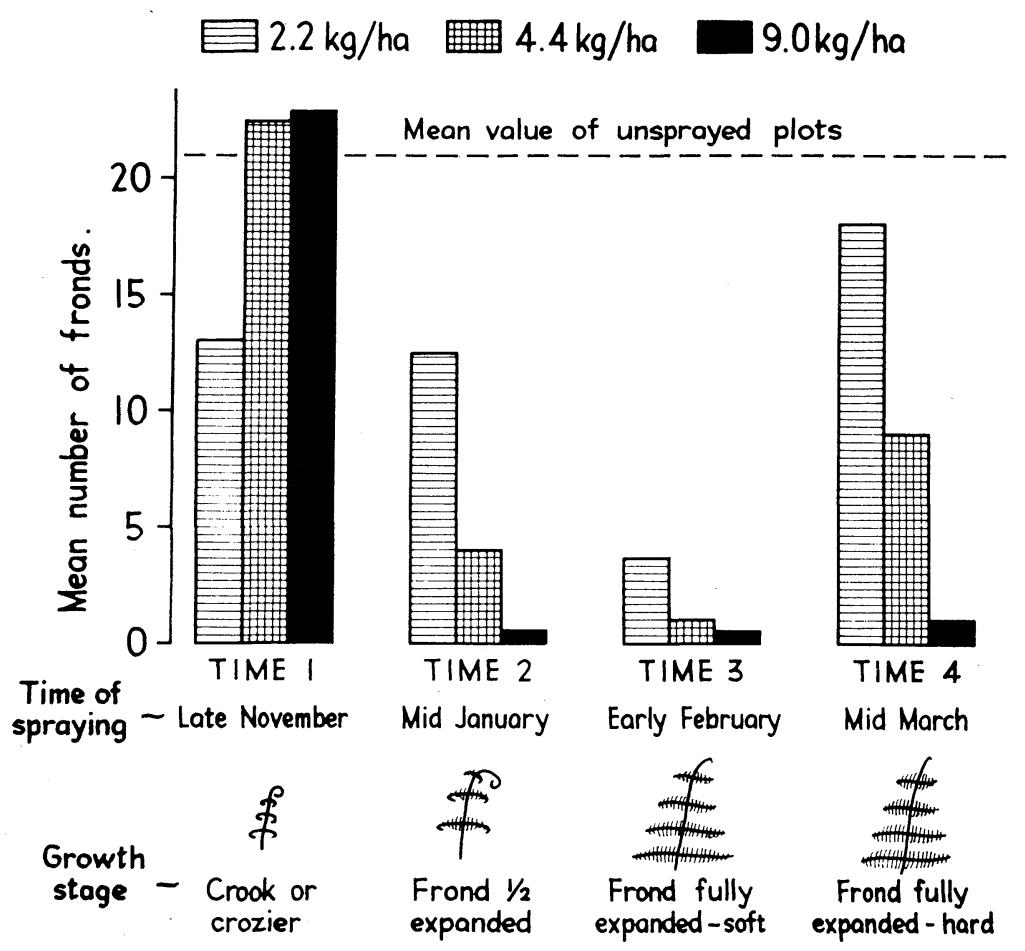

Fig. 1: Long term control of bracken with asulam, assessed from regrowth at 8 to $\mathbf{1 2}$ months after spraying. Mean number of fronds per square metre quadrat.

Asulam applied when the majority of the bracken fronds were fully expanded but still soft gave excellent control after 12 months (Time 3 in Fig. 1). At the optimum time of application even the lowest rate of asulam eramined gave very good control. 
In order to confirm the results of this trial, two similar experienmts were established in 1972/73. Observations on all three will continue. In addition, 4 unreplicated large plot trials gave similar results to those illustrated in Fig. 1, with the best degree of control being obtained following applications made at a stage in frond development corresponding with Time 3.

Since climate, bracken growth and other site factors vary widely throughout New Zealand, several widely dispersed sites were selected where spring regrowth of bracken was causing serious competition to young Pinus radiata seedlings planted the previous winter. At each site asulam was applied late in 1971 by co-operators to 0.1 ha unreplicated plots at $2.2,4.5$ and $9.0 \mathrm{~kg} / \mathrm{ha}$. No other treatment was applied to chemically treated plots, while trees in the unsprayed controls were released from bracken competition at least once using hand slashers.

Since it is difficult to relate assessments of bracken suppression to the degree of tree release, 6 monthly tree height and tree survival rate assessments were used to establish the magnitude of any tree release from bracken competition. Score assessments of the effect of asulam on bracken were also made however, employing a 0 to 5 scale where $0=$ unaffected and $\mathbf{5}=$ complete death of the fronds.

Results

The suppression effect of asulam applied to partially unfurled bracken fronds is illustrated in Fig 2.

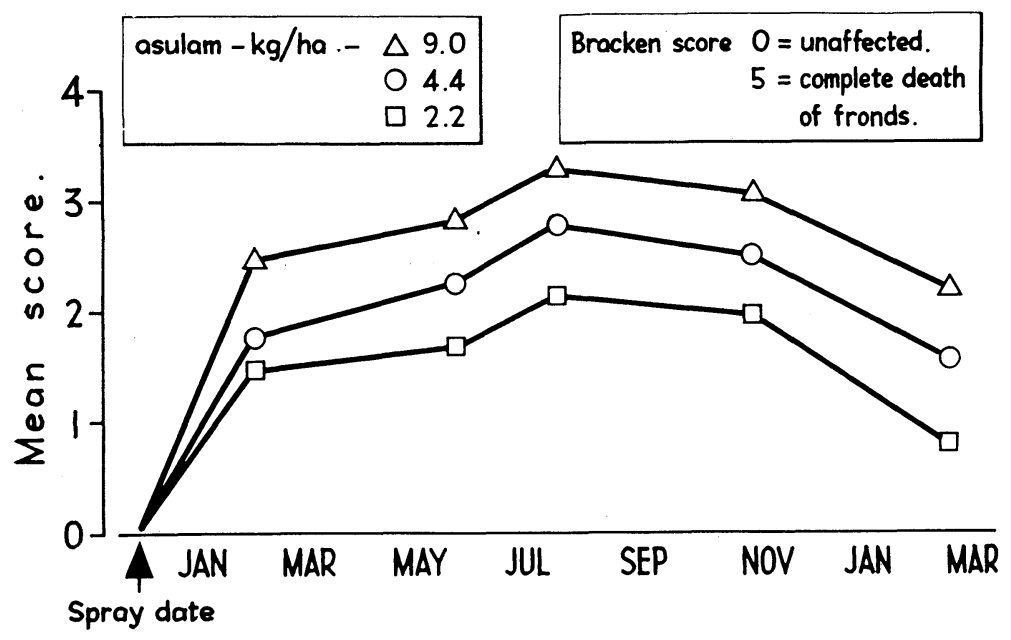

Fig 2: The suppressant effect of asulam following applications made on partially unfurled regrowth. Mean scores from 6 sites pooled.

The consequences of the bracken suppression (Fig. 2) were an increase in mean seedling growth and percentage survival (Fig. 3). Even at the highest rate applied asulam has had no apparent deleterious effects on the young Pinus radiata seedlings. 

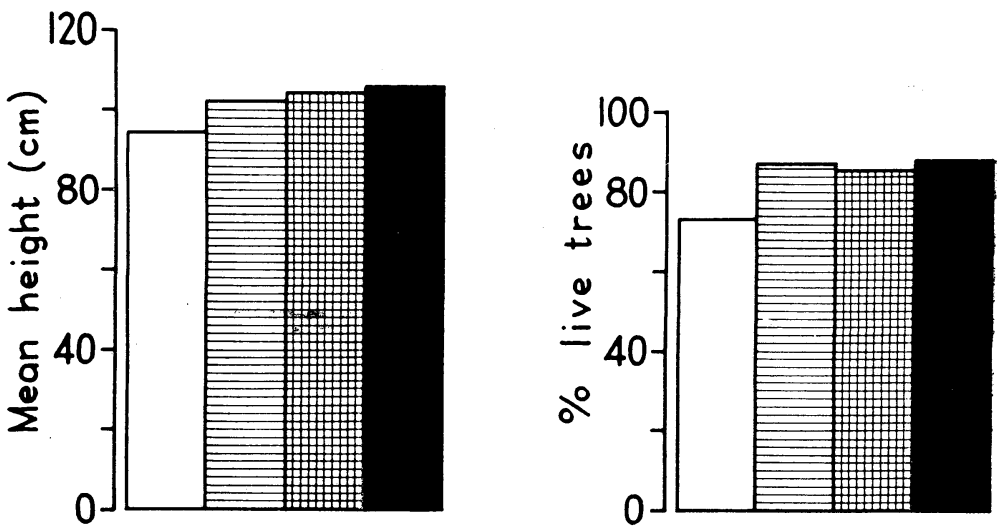

$\square$ unsprayed

\section{$2.2 \mathrm{~kg} / \mathrm{ha} 4.4 \mathrm{~kg} / \mathrm{ha}$}

$9.0 \mathrm{~kg} / \mathrm{ha}$

Fig. 3: The release of Pinus radiata from bracken with asulam. Mean tree height and survival rate assessed 21 months after planting. Data from 4 sites pooled.

To confirm the experimental results described above, 12 operational scale trials of aerially applied asulam were established in various parts of New Zealand. The results of these evaluations are illustrated by score assessments in Table 1.

TABLE 1: SUPPRESSION OF BRACKEN REGROWTH 1 to 3 MONTHS AFTER AERIAL APPLICATIONS OF ASULAM AT $5.6 \mathrm{~kg} / \mathrm{ha}$.

Sites arranged according to date of application

\begin{tabular}{|c|c|c|c|c|c|c|}
\hline \multicolumn{4}{|c|}{ Site No. } & \multirow{2}{*}{$\begin{array}{l}\begin{array}{l}\text { Date of } \\
\text { Application }\end{array} \\
1972\end{array}$} & \multirow[t]{2}{*}{$\begin{array}{l}\text { Growth stage of } \\
\text { majority of fronds } \\
\text { at application }\end{array}$} & \multirow[t]{2}{*}{ Mean Score* } \\
\hline & & & & & & \\
\hline 5 & ...... & ....... & $\ldots \ldots$ & 24 November & $\frac{1}{2}-\frac{2}{3}$ unfurled & 3.50 \\
\hline 10 & $\ldots \ldots$ & $\ldots \ldots$ & $\ldots \ldots$ & 25 November & $\frac{1}{4}$ unfurled & 4.50 \\
\hline 12 & ....... & ....... & $\ldots \ldots$ & 29 November & $\frac{1}{4}$ unfurled & 3.75 \\
\hline 9 & $\ldots \ldots$ & ....... & ....... & 1 December & $\frac{3}{4}$ unfurled & 3.00 \\
\hline 11 & $\ldots \ldots$ & $\ldots \ldots$. & $\ldots \ldots$ & 5 December & $\frac{1}{4}-\frac{1}{2}$ unfurled & 4.00 \\
\hline 8 & $\ldots \ldots$ & $\ldots \ldots$. & $\ldots \ldots$ & 11 December & $\frac{1}{2}-\frac{3}{4}$ unfurled & 3.25 \\
\hline 7 & ....... & $\ldots \ldots$. & & 15 December & $\frac{3}{4}$ unfurled & 3.25 \\
\hline 3 & $\ldots \ldots$ & $\ldots \ldots$ & $\ldots \ldots$ & 16 December & $\frac{2}{3}$ unfurled & \\
\hline & & & & & & 3.50 \\
\hline 2 & ...... & ....... & ...... & 3 January & fully unfurled & 1.75 \\
\hline 1 & $\ldots \ldots$ & $\ldots \ldots$ & $\ldots \ldots$ & 4 January & fully unfurled & 2.00 \\
\hline 4 & ....... & $\ldots \ldots$ & $\ldots \ldots$ & 9 January & fully unfurled & 1.00 \\
\hline 6 & ....... & $\ldots \ldots$ & $\ldots \ldots$ & 9 January & fully unfurled & 1.00 \\
\hline
\end{tabular}

* Mean score of several observers on 0 to 5 scale where $0=$ no effect $5=$ complete kill of fronds. 
The table clearly shows the importance of timing of application and that if applied at the correct stage of frond development a high degree of bracken suppression will be obtained.

\section{DISCUSSION}

The degree of control a year after application of asulam to fully expanded but soft bracken fronds in New Zealand is very similar to that found by Holroyd et al (1970) as well as the other authors previously cited for the United Kingdom variety of bracken. It is also evident that timing is important. Asulam at 4.5 to $9.0 \mathrm{~kg} / \mathrm{ha}$ appears to give bracken control in excess of $80 \%$ at approximately 1 year following spraying, provided that the asulam is applied in the 4 to 6 week period when the fronds are in their most susceptible state. The actual timing of application obviously coincides with bracken frond development and if higher rates of asulam are applied, it appears that successful applications can be made over a longer period.

The suppressant effect of asulam on partially unfurled fronds is of particular interest since it does not appear to have been previously reported. The value of this bracken suppression is very well demonstrated in forestry situations by the tree survival and tree height assessments which confirm the effectiveness of asulam when compared with the hand methods currently employed for tree release from bracken.

It is interesting to note that this suppressant effect following applications made to partially unfurled fronds has started to disappear after only 12 months, whereas applications made for long term bracken control have been most effective when applied to soft, fully expanded fronds.

Veerasekaran and Kirkwood (1972) found that $C^{14}$ labelled asulam moves towards the tips of partially unfurled bracken fronds, whereas basipetal movement of asulam occurs following applications to fully expanded fronds. This difference in assimilate translocation would account for the optimum time of absorption for long term control as reported above and the limited 12 month long bracken suppression following applications to partially unfurled fronds.

\section{ACKNOWLEDGEMENTS}

The author is indebted to officers of the New Zealand Forest Service (Auckland, Wellington, Nelson, Canterbury and Southland Conservancies) as well as Auckland Regional Authority, New Zealand Forest Products, Tasman Pulp \& Paper Co., P. F. Olsen \& Co. and H. Baigent \& Sons and Mr G. Simes of Akaroa for providing sites and other help with trials.

I am also grateful to Mr G. Chavasse of the Forest Research Institute, Rotorua, for advice and criticism and the staff of May \& Baker (New Zealand) Ltd. for trial assistance.

\section{REFERENCES}

Holroyd, J.; Parker, C.; and Rowlands, A., 1970. Asulam for the control of bracken (Pteridium aquilinum (L) Kuhn) Proc. 10th Br. Weed Control Conf.: 371 . 


\section{Scrub Weeds}

Martin, D. J.; Williams, G. H.; and Raymond, J. C., 1972. The effect of asulam on bracken frond number, rhizome viability and frond carbohydrate ratio. Proc. 11th Br. Weed Control Conf.: 331.

Scragg, E. B.; McKelvie, A. D.; and Kilgour, D. W., 1972 Control of bracken with asulam in the north of Scotland. Proc. 11th Br. Weed Control Conf.: 335.

Soper, D., 1972. Review of Bracken control experiments with asulam. Proc. 11th Br. Weed Control Conf,: 24.

Veerasekaran P. and Kirkwood, R. C. (1972). The effect of stage of frond development on the absorption and translocation of asulam in bracken.Proc. 11th Br. Weed Control Conf.: 17.

(chairman's summary continued)

to define the state of our present knowledge of 2,4,5-T plus additive herbicides and their reliability in gorse control. However, fundamental differences in type of gorse chosen on the trial sites and in methods of herbicide application were evident.

These could certainly have resulted in differences in treatment response. Thompson used a mistblower to apply herbicides on regrowth gorse two years after rotary slashing while the other two authors chose untreated natural gorse and application by brushgun. As expected, part of the discussion centred on the choice of treatment recommendations. Although the reliability of the $2,4,5-\mathrm{T} /$ picloram mixture was acknowledged by all three authors, Thompson considered 2,4,5-T was adequately effective if applied in the spring/summer period under normal full coverage spray conditions. Moffat and some discussion participants stated that 2,4,5-T/picloram was the most economic standard gorse treatment. The main consideration justifying this claim was the increase in reliability in regrowth suppression achieved from applications throughout the year and particularly as evidenced by the reduced level of gorse retreatment necessary.

The two papers by Meeklah and Mitchell introduced new subjects to the brushweed session. Control of tutu, an indigenous shrub poisonous to stock and extensively infesting West Otago pastures, was shown to be surprisingly effective with a 2,4-D ester applied as a directed spray or as a granule formulation. Although high rates of the 2,4-D granules were used, the convenience for localised application may warrant this method in conjunction with spray treatment on more extensive accessible infestations. Specific ganule formulation could assist in more effective release and absorption of the 2,4-D in this novel development if extensive aerial treatment is warranted.

- Although the weed scientist may develop new techniques for brush control, the utility of his discoveries much depend on their economic feasibility to the user. The total practical costs of herbicide treatments for sweet brier control were closely examined by Meeklah and Mitchell. From this paper the high country farmer has now been provided with the factors he must critically assess in choosing the methods of chemical treatment for controlling his sweet brier problem. Not only for sweet brier control but also for its application to other weed problems, this paper offers an evaluation worthy of wider circulation in the form of an article in a farmer's journal. 